\title{
High glucose inhibits osteogenic differentiation and proliferation of MC3T3-E1 cells by regulating P2X7
}

\author{
JINSAN YANG, CAO MA and MAOSHU ZHANG \\ Department of Orthopedics, Jining No. 1 People's Hospital, Jining, Shandong 272011, P.R. China
}

Received November 28, 2018; Accepted August 12, 2019

DOI: $10.3892 / \mathrm{mmr} .2019 .10790$

\begin{abstract}
Diabetes mellitus adversely affects human bones and increases the risk of developing osteoporosis. In the present study, treatment with $30 \mathrm{mmol} / \mathrm{l}$ glucose was used to establish a high glucose (HG) cell model in vitro. Plasmids were used to overexpress the $\mathrm{P} 2 \mathrm{X}$ purinoceptor 7 (P2X7) gene. Brilliant blue $\mathrm{G}$ and (4-benzoyl-benzoyl)-ATP were used as a P2X7 antagonist and agonist, respectively. Proliferation of osteogenic MC3T3-E1 cells and alkaline phosphatase (ALP) activity were determined using MTT and colorimetric assays, respectively. Alizarin Red S was used to assess calcification of MC3T3-E1 cells. Western blotting and reverse transcription-quantitative PCR were performed to determine protein and mRNA expression levels. The results demonstrated that HG inhibited MC3T3-E1 cell proliferation and P2X7 expression, reduced calcification, and downregulated the expression levels of ALP and osteocalcin (Ocn) in MC3T3-E1 cells. Overexpression of $\mathrm{P} 2 \mathrm{X} 7$ in $\mathrm{HG}$ conditions increased calcification and proliferation, and upregulated the levels of ALP and Ocn in MC3T3-E1 cells. Inhibition of P2X7 downregulated the expressions of ALP and Ocn in MC3T3-E1 cells under HG conditions. Therefore, the present results indicated that HG caused damage to osteogenic MC3T3-E1 cells. Thus, P2X7 may be a regulatory factor that may be used to counteract the effects of $\mathrm{HG}$ on osteogenesis.
\end{abstract}

\section{Introduction}

As a metabolic disease characterized by hyperglycemia, diabetes mellitus (DM) results from deficient insulin secretion or insulin resistance. The American Diabetes Association indicates that chronic hyperglycemia causes dysfunction in a number of organs, including the eyes, kidneys, nerves, heart and blood vessels (1). It is reported that DM also adversely

Correspondence to: Dr Maoshu Zhang, Department of Orthopedics, Jining No. 1 People's Hospital, 6 Jiankang Road, Jining, Shandong 272011, P.R. China

E-mail: maoshuz_zhangms@163.com

Key words: high glucose, osteogenic MC3T3-E1 cells, P2X purinoceptor 7, osteogenic differentiation affects human bones and is related to an increased risk of developing osteoporosis (2). Osteoporosis is associated with fractures, which lead to morbidity and mortality, particularly in the developed countries $(3,4)$. Children with type 1 diabetes (T1D) have a 5-21\% loss of bone mass, and clinical surveys indicated that patients with DM have a high risk of suffering fractures, including hip, vertebral and tibia fractures, due to insufficient bone mineral density (BMD) (5-8). Lower BMD was reported to be caused by hyperglycemia in patients with T1D (9). High glucose (HG) and MC3T3-E1 cells have been used as an in vitro model to investigate the effects of DM on bone $(10,11)$.

$\mathrm{P} 2 \mathrm{X}$ purinoceptor $7(\mathrm{P} 2 \mathrm{X} 7)$ is a member of the $\mathrm{P} 2 \mathrm{X}$ receptor family, a group of trimeric ligand-gated ion channels (12). The P2X receptors are assembled from seven possible subunits (P2X1-7) $(13,14)$. Extracellular ATP activates P2X family receptors to regulate the passage of $\mathrm{Na}^{+}, \mathrm{Ca}^{2+}$ and other cations (15). P2X subunits share similar membrane topology: Intracellular $\mathrm{N}$ - and $\mathrm{C}$-termini, two membrane-spanning domains, and an extracellular loop containing an ATP binding site $(16,17)$. P2X7 is involved in various physiological and pathophysiological processes, including activation of the inflammasome and inflammatory factors (18), stimulation of metalloproteases (19), and the generation of reactive oxygen and nitrogen species (20). Previous studies reported that P2X7 may be a susceptibility gene in non-obese diabetic mice $(21,22)$. P2X7 has also been reported to be involved in the development of diabetic complications; Portillo et al (23) found that $\mathrm{P} 2 \mathrm{X} 7$ was involved in diabetic retinopathy. The part purinergic system reactivity of $\mathrm{P} 2 \mathrm{X} 7$ was identified to be involved in the pathogenesis of diabetic nephropathy, and antagonizing the $\mathrm{P} 2 \mathrm{X} 7$ receptor may alleviate kidney damage caused by diabetes (24). Wesselius et al (25) demonstrated that the aberrant function of $\mathrm{P} 2 \mathrm{X} 7$ was associated with a low BMD and an increased risk of osteoporosis. P2X7 has been reported to regulate osteoblast activity by potentiating the Wnt/ $\beta$-catenin pathway (26). Therefore, the aim of the present study was to investigate the effect of P2X7 on HG-induced pre-osteoblastic MC3T3-E1 cells.

\section{Materials and methods}

Cell culture. MC-3T3-E1 cells, derived from the bone of a newborn mouse, were purchased from The American Type Culture Collection. MC-3T3-E1 cells were cultured with 
aMEM (Gibco; Thermo Fisher Scientific, Inc.), supplemented with 10\% FBS (Gibco; Thermo Fisher Scientific, Inc.), $100 \mathrm{u} / \mathrm{ml}$ penicillin and $100 \mu \mathrm{g} / \mathrm{ml}$ streptomycin (Gibco; Thermo Fisher Scientific, Inc.), in an incubator with $5 \% \mathrm{CO}_{2}$ at $37^{\circ} \mathrm{C}$. For the $\mathrm{HG}$ group, the dose of $30 \mathrm{mmol} / \mathrm{l}$ glucose was selected; since $\alpha M E M$ already contains $5.5 \mathrm{mmol} / \mathrm{l} \mathrm{D}$-glucose, the media was supplemented with $24.5 \mathrm{mmol} / \mathrm{l} \mathrm{D}$-glucose powder (Gibco; Thermo Fisher Scientific, Inc.) in order to generate the HG conditions. For the mannitol (Man) group, which acted as a control for osmotic pressure, an equal amount of mannitol, $24.5 \mathrm{mmol} / \mathrm{l}$, was added to $\alpha \mathrm{MEM}$ containing $5.5 \mathrm{mmol} / \mathrm{l} \mathrm{D}$-glucose. The cells were cultured for $48 \mathrm{~h}$ with $0,1,2,5,10,20 \mu \mathrm{M}$ Brilliant blue G (BBG; Shanghai Aladdin Bio-Chem Technology., Co., Ltd.).

Reagents. The P2X7 agonist (4-benzoyl-benzoyl)-ATP (BzATP) (27) was purchased from MedChemExpress. The P2X7 antagonist BBG (28) was obtained from Aladdin. Cells were stimulated with BzATP $(300 \mu \mathrm{M})$ or BBG $(10 \mu \mathrm{M})$ at a final concentration 300 or $10 \mu \mathrm{M}$ for $2 \mathrm{~h}$ at room temperature. Application of PBS was used as the control.

Cell transfection. Cells were seeded in $35 \mathrm{~mm}$ plates $24 \mathrm{~h}$ prior to transfection experiments. Then, $50 \mathrm{nmol}$ of $\mathrm{P} 2 \mathrm{X} 7$ and mock (empty vector) plasmids were purchased from Cobioer Biosciences Co., Ltd. Lipofectamine ${ }^{\circledR}$ (Invitrogen; Thermo Fisher Scientific, Inc.) was diluted in Opti-MEM (Invitrogen; Thermo Fisher Scientific, Inc.). The plasmids and Lipofectamine ${ }^{\circledR}$ solution were added to tubes containing FBS-free $\alpha M E M$. The mixed solution was added to the cells for $2 \mathrm{~h}$, after which the medium was removed and replaced with fresh complete culture medium. The cells were cultured for a further 24 or $48 \mathrm{~h}$.

Cell viability. MTT was used to determine the levels of cell viability. MTT was dissolved in PBS to a concentration of $5 \mathrm{mg} / \mathrm{ml}$. The cells $\left(5 \times 10^{3}\right)$ were seeded in 96 -well plates for $24 \mathrm{~h}$ in a $5 \% \mathrm{CO}_{2}$ incubator at $37^{\circ} \mathrm{C}$. After the cells were treated for 24 or $48 \mathrm{~h}$, the culture medium was removed. MTT solution $(5 \mathrm{mg} / \mathrm{ml})$ was diluted to a concentration of $0.5 \mathrm{mg} / \mathrm{ml}$ with FBS-free $\alpha$ MEM. MTT working solution $(200 \mu \mathrm{l})$ was added to each well and incubated for $2 \mathrm{~h}$ in a $5 \% \mathrm{CO}_{2}$ incubator at $37^{\circ} \mathrm{C}$. The MTT working solution was discarded, and $100 \mu 1 \mathrm{DMSO}$ was added to each well for $10 \mathrm{~min}$ at $37^{\circ} \mathrm{C}$. The absorbance was determined using a microplate reader at a wavelength of $570 \mathrm{~nm}$.

Colorimetric assay for alkaline phosphatase (ALP). After the cells had been treated with the reagents as aforementioned for $48 \mathrm{~h}$, protein was extracted using cell lysis buffer (Thermo Fisher Scientific, Inc.) on ice, followed by centrifugation at $20,000 \mathrm{x} \mathrm{g}$ for $15 \mathrm{~min}$ at $4^{\circ} \mathrm{C}$. The concentration of total protein was determined using the bicinchoninic acid (BCA) method. A nitrophenyl phosphate kit (Beijing Leagene Biotech Co., Ltd.) was used to determine ALP activity, according to the manufacturer's instructions. The absorbance was detected using a spectrophotometer at a wavelength of $405 \mathrm{~nm}$.

Alizarin Red $S$ assay. The cells $\left(2 \times 10^{4}\right.$ cells $\left./ \mathrm{cm}^{2}\right)$ were seeded in 6-well plates and treated for $48 \mathrm{~h}$, as aforementioned. The cells were cultured using complete culture medium supplemented with vitamin C (50 $\mu \mathrm{g} / \mathrm{ml}$; Sigma-Aldrich; Merck $\mathrm{KGaA}$ ) and $\beta$-phosphoglycerol (10 mmol/1; Sigma-Aldrich; Merck $\mathrm{KGaA}$ ) for 20 days. After removing the medium, PBS was used to wash the cells three times. The cells were fixed using $0.05 \%$ glutaraldehyde in $\mathrm{H}_{2} \mathrm{O}$ for $10 \mathrm{~min}$ at room temperature and washed three times with PBS. Alizarin Red S solution (0.4\%; Beijing Solarbio Science and Technology Co., Ltd.) was used to stain the cells for $5 \mathrm{~min}$ at room temperature. After washing with PBS, images of the cells were captured using a light microscope (magnification, x200; Olympus Corporation).

Western blot analysis. Total protein was extracted from MC-3T3-E1 cells using cell lysis as aforementioned, and the concentration was determined using the BCA method. A protein ladder (Thermo Fisher Scientific, Inc.) and (20 $\mu \mathrm{g} / \mathrm{lane})$ protein samples were separated using 10\% SDS-PAGE. The proteins were transferred to PVDF membranes, which were blocked with 5\% BSA for $2 \mathrm{~h}$ at room temperature. The following primary antibodies were incubated with the membranes overnight at $4^{\circ} \mathrm{C}$ : P2X7 (cat. no. ab109054; 1:1,000; Abcam) and $\beta$-actin (cat. no. ab8227; 1:1,000; Abcam). The membranes were washed three times with TBS with $0.05 \%$ Tween-20 (TBST), incubated with a horseradish peroxidase-conjugated anti-rabbit secondary antibody (cat. no. ab7090; 1:1,000; Abcam) at room temperature for $2 \mathrm{~h}$, and then washed three times with TBST. Protein bands were visualized using ECL (Thermo Fisher Scientific, Inc.). An E-gel imager (Thermo Fisher Scientific, Inc.) was used to capture images and ImageJ (version 1.8, National Institutes of Health) was used for densitometry analysis.

Reverse transcription-quantitative PCR (RT-qPCR). Total RNA was extracted from MC-3T3-E1 cells using TRIzol (Invitrogen; Thermo Fisher Scientific, Inc.), followed by centrifugation for $10 \mathrm{~min}$ at $16,000 \mathrm{xg}$ at $4^{\circ} \mathrm{C}$. Total RNA was dissolved in $\mathrm{ddH} 2 \mathrm{O}$ and a spectrophotometer was used to detect the RNA concentration at a wavelength of $260 \mathrm{~nm}$. Total RNA was reverse transcribed using a cDNA reverse transcription kit (High-Capacity cDNA reverse transcription kit, Applied Biosystems; Thermo Fisher Scientific, Inc.) at $42^{\circ} \mathrm{C}$ for $15 \mathrm{~min}$ and $95^{\circ} \mathrm{C}$ for $3 \mathrm{~min}$. RT-qPCR was conducted on ABI 7500 Real-time PCR system (Applied Biosystems; Thermo Fisher Scientific, Inc.) using SYBR green (Invitrogen; Thermo Fisher Scientific, Inc.). The following primers were used for qPCR: P2X7 forward, 5'-CTTCGGCGTGCGTTTTG-3' and reverse, 5'-AGGACA GGGTGGATCCAATG-3'; ALP forward, 5'-CAGTGGTAT TGTAGGTGCTGTG-3' and reverse, 5'-TTTCTGCTTGAG GTTGAGGTTAC-3'; osteocalcin (Ocn) forward, 5'-GGC GTCCTGGAAGCCAATGTG-3' and reverse, 5'-GACCAG GAGGACCAGGAAGTCCACGT-3'; and $\beta$-actin forward, 5'-AGCAGAGAATGGAAAGTCAAA-3' and reverse, 5'-ATGCTGCTTACATGTCTCGAT-3'. The conditions of the qPCR were as follows: $95^{\circ} \mathrm{C}$ for $1 \mathrm{~min}$, followed by 40 cycles of $95^{\circ} \mathrm{C}$ for $30 \mathrm{sec}, 62^{\circ} \mathrm{C}$ for $60 \mathrm{sec}$ and $72^{\circ} \mathrm{C}$ for $30 \mathrm{sec}$, with a final extension at $72^{\circ} \mathrm{C}$ for $90 \mathrm{sec}$. The relative mRNA expression levels were analyzed using the $2^{-\Delta \Delta \mathrm{Cq}}$ method (29). 

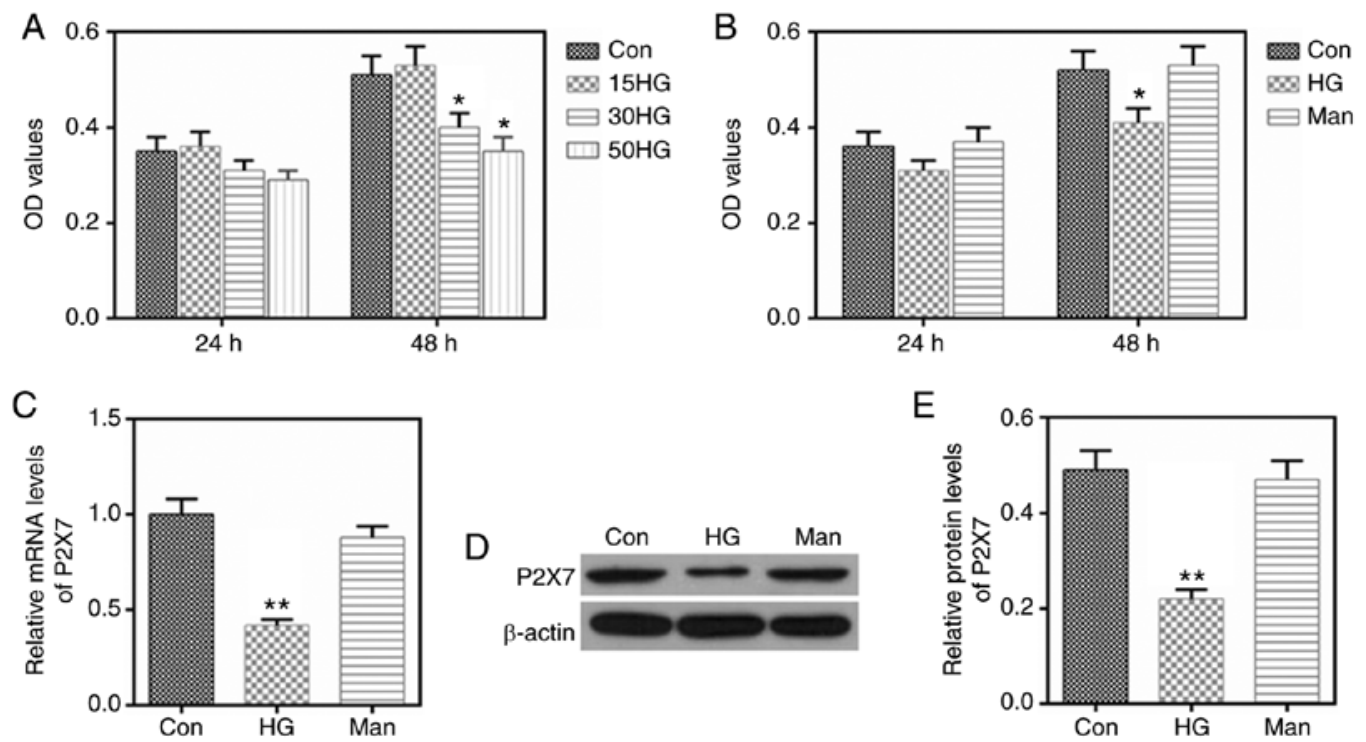

Figure 1. HG inhibits MC3T3-E1 cell proliferation and P2X7 expression. (A) MC3T3-E1 cells were cultured with medium containing 15, 30 or 50 mmol/1 D-glucose for 24 or $48 \mathrm{~h}$. Cell viability was then assessed by MTT assay. (B) MC3T3-E1 cells were cultured with medium containing $30 \mathrm{mmol} / 1 \mathrm{D}$-glucose or $24.5 \mathrm{mmol} / \mathrm{l}$ Man for 24 or $48 \mathrm{~h}$. MTT assay was then used to determine cell viability. (C) mRNA expression levels of P2X7 were determined by reverse transcription-quantitative PCR. (D) P2X7 protein expression levels were determined by western blot analysis. (E) Quantification of western blot analysis. Data are presented as the mean $\pm \mathrm{SD}$. ${ }^{\mathrm{P}}<0.05$ and ${ }^{* *} \mathrm{P}<0.001$ vs. Con group. HG, high glucose; P2X7, P2X purinoceptor 7; Man, mannitol; Con, control; OD, optical density.

Statistical analysis. Data are presented as the mean $\pm \mathrm{SD}$ from three independent experiments and were analyzed using one-way ANOVA followed by Turkey's multiple comparison test. Data were analyzed using SPSS 21.0 (IBM Corp.). $\mathrm{P}<0.05$ was considered to indicate a statistically significant difference.

\section{Results}

$H G$ reduces $M C-3 T 3-E 1$ proliferation and the expression of $P 2 X$. Stimulation with 30 and $50 \mathrm{mmol} / \mathrm{l}$ glucose significantly inhibited the proliferation of MC-3T3-E1 cells (Fig. 1A); therefore, the dose of $30 \mathrm{mmol} / \mathrm{l}$ glucose was selected as $\mathrm{HG}$ conditions to treat MC-3T3-E1 cells in the subsequent experiments. To control for the effect of osmotic pressure, Man was used as a control group (Fig. 1B). The osmotic pressure created by Man, that would be equivalent to the HG conditions, did not affect cell proliferation (Fig. 1B). Furthermore, HG was found to inhibit the expression of P2X7, both at the mRNA and the protein level (Fig. 1C-E).

$H G$ inhibits calcification and the levels of ALP and Ocn in $M C$-3T3-E1 cells. Next, the present study investigated whether HG affected calcification, and the expression levels of ALP and Ocn. The results indicated that HG stimulation downregulated the mRNA expression levels of ALP and Ocn (Fig. 2F). In addition, the Alizarin Red S staining in the HG group was markedly lighter compared with the control group (Fig. 2G), which suggested that HG stimulation resulted in reduced calcification in MC-3T3-E1 cells.

Overexpression of $P 2 X 7$ increases calcification, proliferation and the levels of ALP and Ocn expression in MC-3T3-E1 cells under $H G$ conditions. First, successful P2X7 overexpression was confirmed, both at the mRNA and the protein level, in
MC-3T3-E1 cells (Fig. 2C-E). Overexpression of P2X7 had no significant promotion effect on the cell proliferation of MC-3T3-E1 cells under HG conditions (Fig. 2A). In addition, P2X7 overexpression enhanced ALP activity and upregulated the expression of ALP, under both normal glucose or HG conditions (Fig. 2B and F). P2X7 overexpression also increased the mRNA expression levels of Ocn, under both normal glucose or HG conditions (Fig. 2F). The Alizarin Red S staining analysis revealed no difference between the $\mathrm{P} 2 \mathrm{X} 7$ overexpression group and the control group; however, the $\mathrm{HG}+\mathrm{P} 2 \mathrm{X} 7$ group had a darker Alizarin Red S staining than the HG alone group (Fig. 2G), suggesting that P2X7 overexpression improved calcification in MC-3T3-E1 cells.

Inhibition of $P 2 X 7$ reduces the levels of $A L P$ and $O c n$ in MC-3T3-El cells under $H G$ conditions. To investigate the effect of P2X7 on MC-3T3-E1 cells in HG conditions, the P2X7 antagonist BBG was used. The results demonstrated that $10 \mu \mathrm{M}$ BBG had no significant effect on cell viability (Fig. 3A). BBG treatment $(10 \mu \mathrm{M})$ inhibited the activity of ALP (Fig. 3B), the mRNA and protein expression of P2X7 (Fig. 3C-E), and the mRNA expression levels of ALP and Ocn (Fig. 3F). By contrast, overexpression of P2X7 partially reversed the effects of $\mathrm{BBG}$ on above the gene expression with or without HG treatment (Fig. 3C and F).

Activation of $P 2 X 7$ increases the expression of ALP and Ocn in MC-3T3-El cells under $H G$ conditions. To further investigate the role of $\mathrm{P} 2 \mathrm{X} 7$, cells were treated with the $\mathrm{P} 2 \mathrm{X} 7$ agonist BzATP. BzATP treatment promoted ALP activity (Fig. 4A) and upregulated the expression of ALP and Ocn (Fig. 4E). Overexpression of P2X7 increased the effects of BzATP (Fig. 4A-E). BzATP in combination with the overexpression of $\mathrm{P} 2 \mathrm{X} 7$ promoted ALP activity and further upregulated the expression of ALP and Ocn in the HG group. 

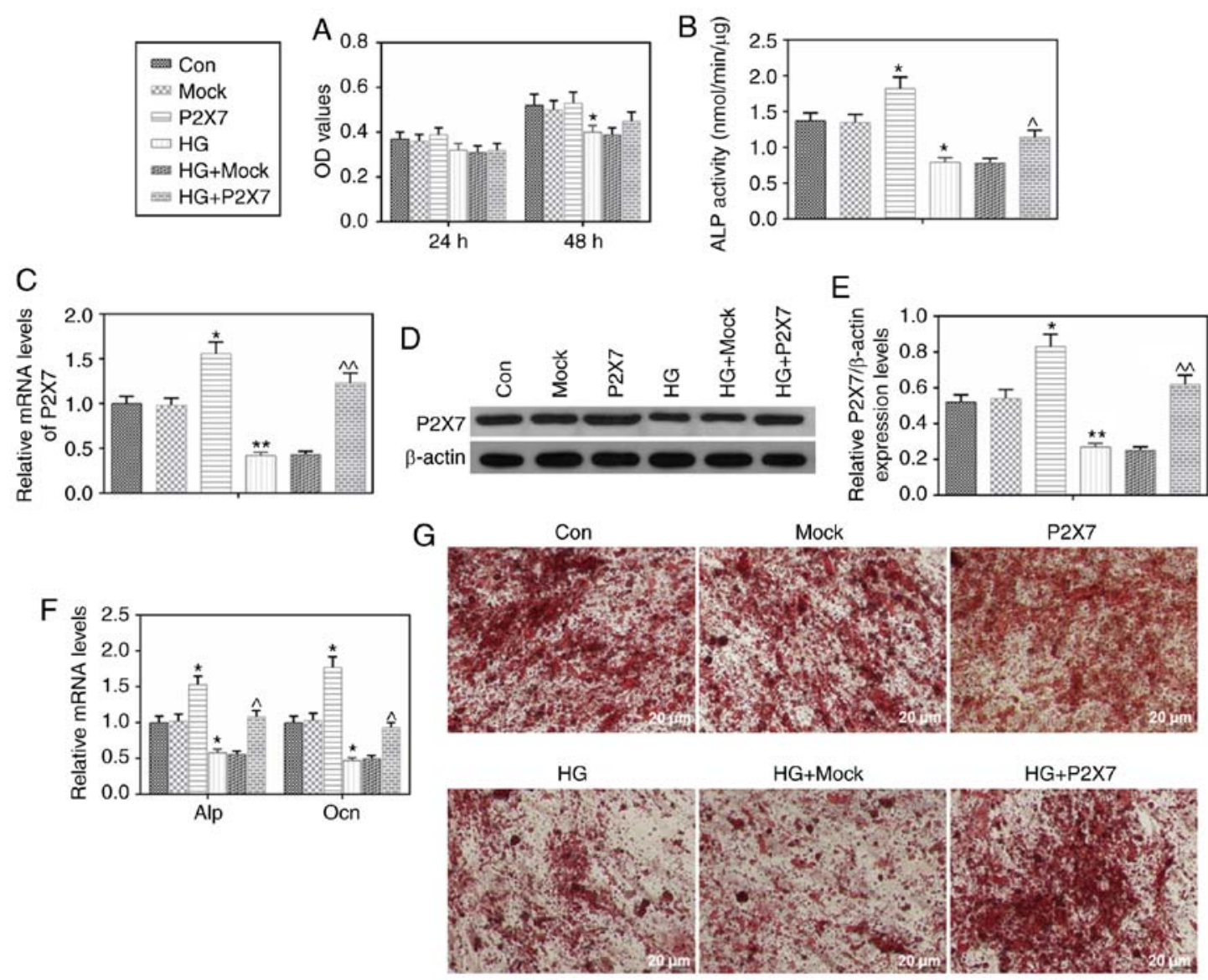

$\mathrm{P} 2 \mathrm{X} 7$

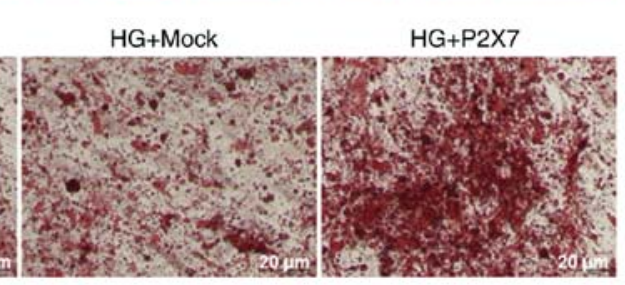

Figure 2. Effects of HG and P2X7 on calcification and the expression levels of ALP and Ocn in MC3T3-E1 cells. MC3T3-E1 cells were transfected with mock or P2X7-overexpressing plasmids, under normal or HG $(30 \mathrm{mmol} / \mathrm{l})$ conditions. (A) After $24 \mathrm{or} 48 \mathrm{~h}$ of treatments, MTT assay was used to determine cell viability. (B) After treatments as indicated for $8 \mathrm{~h}$, a nitrophenyl phosphate kit was used to determine ALP activity. (C) After treatments as indicated for $48 \mathrm{~h}$, mRNA expression levels of P2X7 were determined by RT-qPCR. (D) After treatments for $48 \mathrm{~h}, \mathrm{P} 2 \mathrm{X} 7$ protein expression levels were determined by western blot analysis. (E) Quantification of the western blot analysis. (F) After treatments as indicated for $48 \mathrm{~h}$, mRNA expression levels of ALP and Ocn were determined by RT-qPCR. (G) Alizarin Red S staining was used to assess calcification in the MC3T3-E1 cells. Data are presented as the mean \pm SD. ${ }^{*} \mathrm{P}<0.05$ and ${ }^{* *} \mathrm{P}<0.001$ vs. Con; ${ }^{\wedge} \mathrm{P}<0.05$ and ${ }^{\wedge} \mathrm{P}<0.001$ vs. HG. HG, high glucose; P2X7, P2X purinoceptor 7; ALP, alkaline phosphatase; Ocn, osteocalcin; RT-qPCR, reverse transcription-quantitative PCR; Con, control.

\section{Discussion}

The present study demonstrated that HG stimulation caused damage to osteogenic MC3T3-E1 cells, with the damage becoming more serious if glucose at a high concentration was used to treat MC3T3-E1 cells for an extended period of time. HG resulted in the reduced expression of P2X7 in osteogenic MC3T3-E1 cells.

ALP is a plasma membrane-bound glycoprotein (30). The mammalian ALP is a zinc-containing metalloenzyme encoded for by a multigene family. ALP is expressed in the placenta, intestine, liver, kidneys and bone (30). Romagnoli et al (31) reported that the expression of ALP in bones is useful in clinical practice. ALP can be used as a marker to assess osteoblast activity and decreased serum ALP activity reduces osteogenesis $(32,33)$. In the present study, HG stimulation decreased the activity and expression of ALP, suggesting that HG reduced osteogenesis. Furthermore, HG inhibited the calcification of osteoblasts. However, overexpression of P2X7 in osteogenic MC3T3-E1 cells attenuated the effects of HG and promoted osteogenesis and calcification. A previous study has found that osteoblasts regulated glucose homeostasis, which is an aspect of energy metabolism, by conducting studies on an animal model and conducting cell biology experiments (34). Another previous study demonstrated that osteoblasts stimulate insulin secretion and that this function was regulated by Ocn, suggesting that osteoblasts act as endocrine cells (35). Genetic evidence from mice suggest that G-protein coupled receptor family (GPRC6A) is important for Ocn in regulating insulin secretion and expression (36). GPRC6A is a master regulator of complex endocrine networks and metabolic processes, including insulin, bone, liver metabolism and fat metabolism, and immune function (37). In the present study, HG stimulation decreased the expression of Ocn, with the overexpression of P2X7 in osteogenic MC3T3-E1 cells increasing Ocn expression under HG conditions, indicating that HG may attenuate the ability of osteoblasts to secrete insulin and that the overexpression of $\mathrm{P} 2 \mathrm{X} 7$ may improve insulin secretion.

To further analyze the role of $\mathrm{P} 2 \mathrm{X} 7$ in osteoblasts under HG conditions, BBG and BzATP were used to antagonize and activate $\mathrm{P} 2 \mathrm{X} 7$ function, respectively. The present results demonstrated that overexpression of $\mathrm{P} 2 \mathrm{X} 7$ promoted the differentiation of MC3T3-E1. BBG had no significant effect on cell viability, indicating that BBG had no obvious toxicity to cells. 


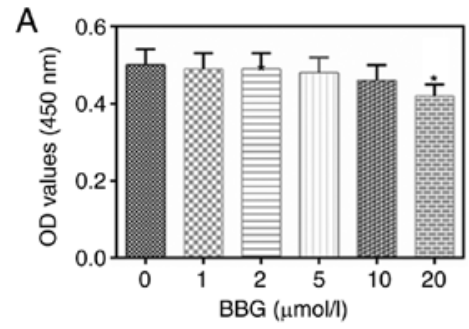

B
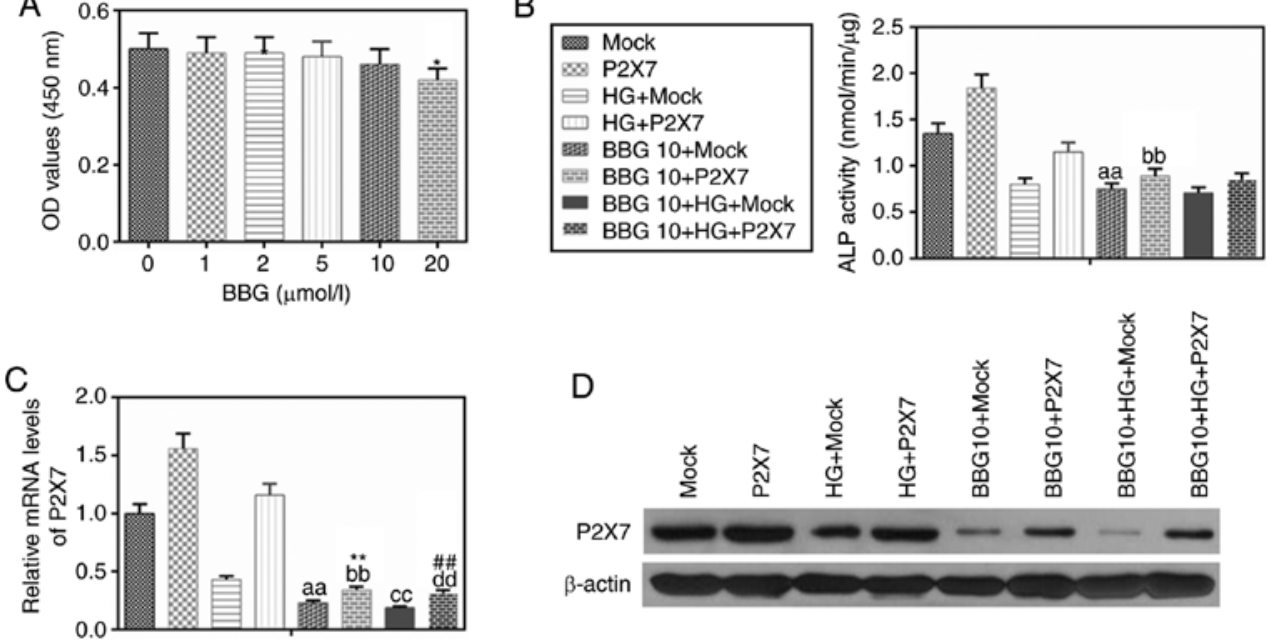

$\mathrm{P} 2 \mathrm{X} 7$

$\beta$-actin

$\mathrm{E}$
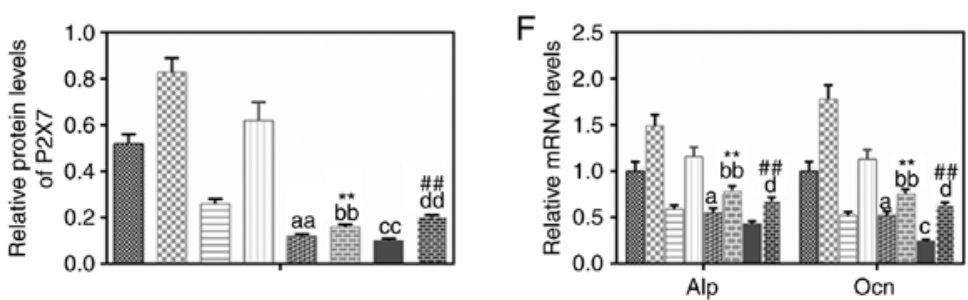

Figure 3. BBG inhibits the expressions of P2X7, ALP and Ocn in MC3T3-E1 cells under HG conditions. BBG (10 $\mu$ mol/1), P2X7 overexpression, mock or their combination were used to treat MC3T3-E1 cells for $48 \mathrm{~h}$ under normal or HG $(30 \mathrm{mmol} / \mathrm{l})$ conditions. (A) MTT was used to determine cell viability at different BBG concentrations. (B) A nitrophenyl phosphate kit was used to determine ALP activity. (C) mRNA expression levels of P2X7 were determined by RT-qPCR (D) P2X7 protein expression levels were analyzed by western blot analysis. (E) Quantification of the western blot analysis. (F) mRNA expression levels of ALP and Ocn were determined by RT-qPCR. Data are presented as the mean \pm SD. ${ }^{*} \mathrm{P}<0.05$ vs. $0 \mu \mathrm{mol} / 1 \mathrm{BBG}$; ${ }^{\mathrm{a}} \mathrm{P}<0.05$ and ${ }^{\text {aa }} \mathrm{P}<0.001$ vs. Mock; ${ }^{\text {bb }} \mathrm{P}<0.001$ vs. $\mathrm{P} 2 \mathrm{X} 7 ;{ }^{\circ} \mathrm{P}<0.05$ and ${ }^{\mathrm{cc}} \mathrm{P}<0.001$ vs. $\mathrm{HG}+\mathrm{Mock}$; ${ }^{\mathrm{P}}<0.05$ and ${ }^{\mathrm{dd}} \mathrm{P}<0.001$ vs. $\mathrm{HG}+\mathrm{P} 2 \mathrm{X} 7 ;{ }^{* *} \mathrm{P}<0.001$ vs. BBG10+Mock; ${ }^{\# / \mathrm{P}}<0.001$ vs. BBG10+HG+Mock. BBG, Brilliant blue G; P2X7, P2X purinoceptor 7; ALP, alkaline phosphatase; Ocn, osteocalcin; HG, high glucose; RT-qPCR, reverse transcription-quantitative PCR; Con, control; OD, density.
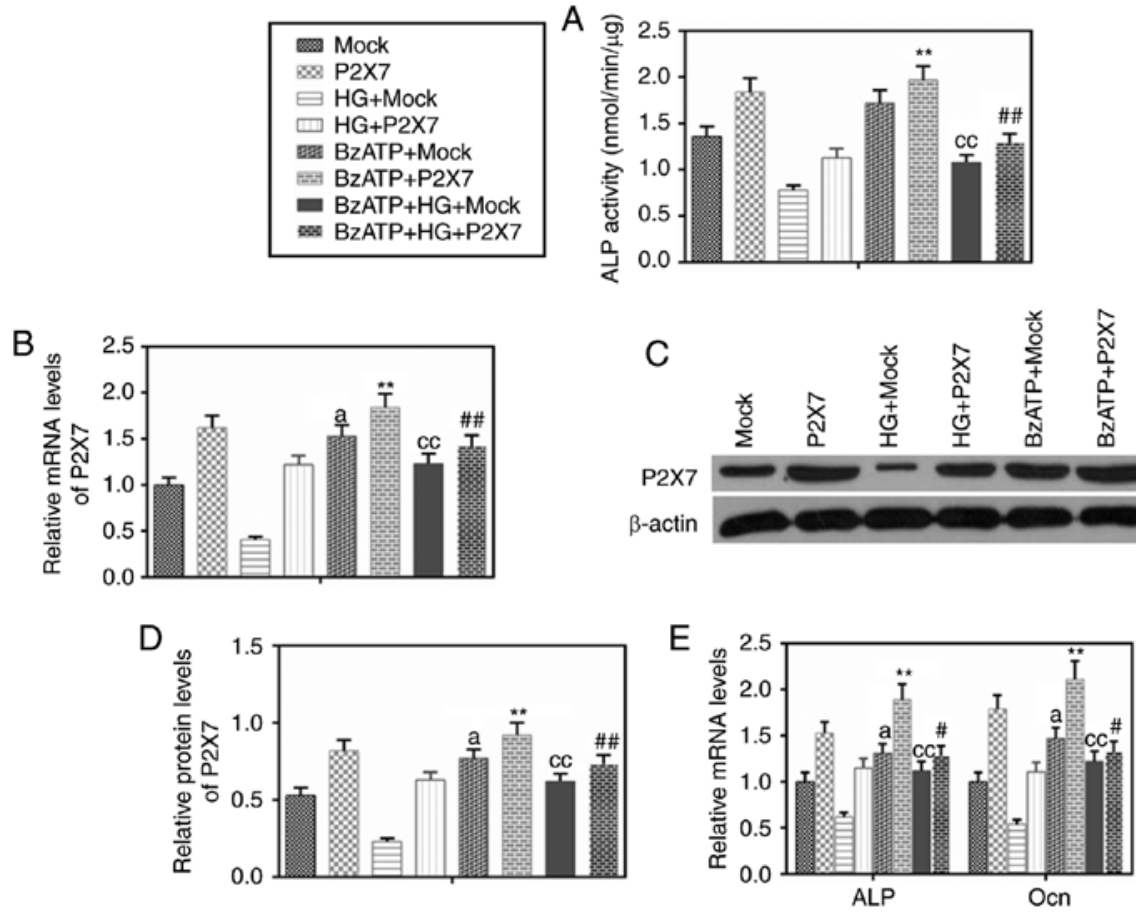

Figure 4. BzATP promotes the expression of P2X7, ALP and Ocn in MC3T3-E1 cells under HG conditions. BzATP (300 $\mu$ mol/1), P2X7 overexpression, mock or their combination were used to treat MC3T3-E1 cells for $48 \mathrm{~h}$ under normal or $\mathrm{HG}(30 \mathrm{mmol} / \mathrm{l})$ conditions. (A) A nitrophenyl phosphate kit was used to determine ALP activity. (B) mRNA expression levels of P2X7 were determined by RT-qPCR. (C) P2X7 protein expression levels were determined by western blot analysis. (D) Quantification of the western blot analysis. (E) mRNA expression levels of ALP and Ocn were determined by RT-qPCR. Data are presented as the mean \pm SD

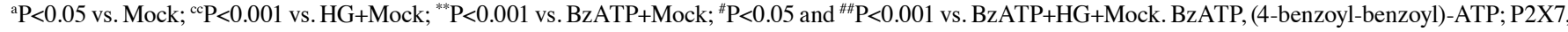
P2X purinoceptor 7; ALP, alkaline phosphatase; Ocn, osteocalcin; HG, high glucose; RT-qPCR, reverse transcription-quantitative PCR; Con, control. 
In addition, BBG and BzATP participated in the differentiation of osteoblast MC3T3-E1 by regulating the function of P2X7. In addition, the overexpression of $\mathrm{P} 2 \mathrm{X} 7$ partially reversed the effects of BBG with or without HG treatment. Wu et al (38) used a hyperglycemic mice model to investigate the effect of $\mathrm{HG}$ on bone formation and bone resorption. Nicke et al (39) describe a novel P2X7 isoform with distinct functional properties that contributes to the diversity of $\mathrm{P} 2 \mathrm{X} 7$ receptor signaling. In the present study, it was demonstrated that HG caused damage to osteogenic MC3T3-E1 cells and that the overexpression of $\mathrm{P} 2 \mathrm{X} 7$ increased osteogenic differentiation and proliferation of MC3T3-E1 cells. It was also found that inhibiting P2X7 decreased osteogenesis under HG conditions. Therefore, the findings of the present study suggested that $\mathrm{P} 2 \mathrm{X} 7$ may be a regulator of the action of $\mathrm{HG}$ on osteogenic MC3T3-E1 cells. Future studies will be required to provide a more in-depth validation experiments of $\mathrm{P} 2 \mathrm{X} 7$ in osteoblasts under $\mathrm{HG}$ conditions.

In conclusion, the present study indicated that $\mathrm{HG}$ stimulation inhibited the proliferation and differentiation of osteoblasts by downregulating the expression of P2X7, and that activating $\mathrm{P} 2 \mathrm{X} 7$ could significantly improve the function of osteoblasts under HG conditions. However, the role of P2X7 in insulin and glucose metabolism requires further investigation, since the present study did not examine the relationship between P2X7 and GPRC6A. In addition, the culture of cells in $\mathrm{HG}$ conditions could affect cell viability, which may also affect osteoblast differentiation.

\section{Acknowledgements}

Not applicable.

\section{Funding}

No funding was received.

\section{Availability of data and materials}

The datasets used and/or analyzed during the current study are available from the corresponding author on reasonable request.

\section{Authors' contributions}

JY and MZ made substantial contributions to the conception and design of the present study. JY and CM were involved in data acquisition, data analysis and interpretation All authors were involved in drafting the article or critically revising it for important intellectual content and gave final approval of the version to be published. All authors agree to be accountable for all aspects of the work in ensuring that questions related to the accuracy or integrity of the work are appropriately investigated and resolved.

\section{Ethics approval and consent to participate}

Not applicable.

\section{Patient consent for publication}

Not applicable.

\section{Competing interests}

The authors declare that they have no competing interests.

\section{References}

1. American Diabetes Association: Diagnosis and classification of diabetes mellitus. Diabetes Care 35 (Suppl 1): S64-S71, 2012.

2. Hamann C, Kirschner S, Günther KP and Hofbauer LC: Bone, sweet bone-osteoporotic fractures in diabetes mellitus. Nat Rev Endocrinol 8: 297-305, 2012.

3. Kurra S, Fink DA and Siris ES: Osteoporosis-associated fracture and diabetes. Endocrinol Metab Clin North Am 43: 233-243, 2014.

4. Johnell $\mathrm{O}$ and Kanis JA: An estimate of the worldwide prevalence and disability associated with osteoporotic fractures. Osteoporosis Int 17: 1726-1733, 2006.

5. Loureiro MB, Ururahy MA, Freire-Neto FP, Oliveira GH, Duarte VM, Luchessi AD, Brandão-Neto J, Hirata RD, Hirata MH, Maciel-Neto JJ, et al: Low bone mineral density is associated to poor glycemic control and increased OPG expression in children and adolescents with type 1 diabetes. Diabetes Res Clin Pract 103: 452-457, 2014.

6. Janghorbani M, Feskanich D, Willett WC and Hu F: Prospective study of diabetes and risk of hip fracture: The nurses' health study. Diabetes Care 29: 1573-1578, 2006.

7. Gunczler P, Lanes R, Paoli M, Martinis R, Villaroel O and Weisinger JR: Decreased bone mineral density and bone formation markers shortly after diagnosis of clinical type 1 diabetes mellitus. J Pediatr Endocrinol Metab 14: 525-528, 2001.

8. Kemink SA, Hermus AR, Swinkels LM, Lutterman JA and Smals AG: Osteopenia in insulin-dependent diabetes mellitus; prevalence and aspects of pathophysiology. J Endocrinol Invest 23: 295-303, 2000.

9. Vestergaard P: Discrepancies in bone mineral density and fracture risk in patients with type 1 and type 2 diabetes-a meta-analysis. Osteoporosis Int 18: 427-444, 2007.

10. Cunha JS, Ferreira VM, Maquigussa E, Naves MA and Boim MA: Effects of high glucose and high insulin concentrations on osteoblast function in vitro. Cell Tissue Res 358: 249-256, 2014.

11. Gong K, Qu B, Wang C, Zhou J, Liao D, Zheng W and Pan X: Peroxisome proliferator-activated receptor a facilitates osteogenic differentiation in MC3T3-E1 cells via the Sirtuin 1-dependent signaling pathway. Mol Cells 40: 393-400, 2017.

12. North RA: P2X receptors. Philos Trans R Soc Lond B Biol Sci 371: pii: 20150427, 2016.

13. Nicke A, Bäumert HG, Rettinger J, Eichele A, Lambrecht G, Mutschler E and Schmalzing G: P2X1 and P2X3 receptors form stable trimers: A novel structural motif of ligand-gated ion channels. EMBO J 17: 3016-3028, 1998.

14. Aschrafi A, Sadtler S, Niculescu C, Rettinger J and Schmalzing G: Trimeric architecture of homomeric $\mathrm{P} 2 \mathrm{X} 2$ and heteromeric P2X1+2 receptor subtypes. J Mol Biol 342: 333-343, 2004.

15. Burnstock $G$ and Kennedy C: P2X receptors in health and disease. Adv Pharmacol 61: 333-372, 2011.

16. Baconguis I, Hattori M and Gouaux E: Unanticipated parallels in architecture and mechanism between ATP-gated P2X receptors and acid sensing ion channels. Curr Opin Struct Biol 23: 277-284, 2013.

17. Schneider M, Prudic K, Pippel A, Klapperstück M, Braam U, Müller CE, Schmalzing $G$ and Markwardt F: Interaction of Purinergic P2X4 and P2X7 receptor subunits. Front Pharmacol 8: 860, 2017.

18. Dubyak GR: P2X7 receptor regulation of non-classical secretion from immune effector cells. Cell Microbiol 14: 1697-1706, 2012.

19. Pupovac A and Sluyter R: Roles of extracellular nucleotides and $\mathrm{P} 2$ receptors in ectodomain shedding. Cell Mol Life Sci 73: 4159-4173, 2016.

20. Miller CM, Boulter NR, Fuller SJ, Zakrzewski AM, Lees MP, Saunders BM, Wiley JS and Smith NC: The role of the P2X receptor in infectious diseases. PLoS Pathog 7: e1002212, 2011.

21. Coutinho-Silva R, Robson T, Beales PE and Burnstock G: Changes in expression of $\mathrm{P} 2 \mathrm{X} 7$ receptors in NOD mouse pancreas during the development of diabetes. Autoimmunity 40: 108-116, 2007.

22. Menzies RI, Booth JWR, Mullins JJ, Bailey MA, Tam FWK, Norman JT and Unwin RJ: Hyperglycemia-induced renal P2X7 receptor activation enhances diabetes-related injury. EBioMedicine 19: 73-83, 2017. 
23. Portillo JC, Lopez Corcino Y, Miao Y, Tang J, Sheibani N, Kern TS, Dubyak GR and Subauste CS: CD40 in retinal Muller cells induces P2X7-dependent cytokine expression in macrophages/microglia in diabetic mice and development of early experimental diabetic retinopathy. Diabetes 66: 483-493, 2017.

24. Kreft E, Kowalski R, Jankowski M and Szczepanska-Konkel M Renal vasculature reactivity to agonist of $\mathrm{P} 2 \mathrm{X} 7$ receptor is increased in streptozotocin-induced diabetes. Pharmacol Rep 68: 71-74, 2016.

25. Wesselius A, Bours MJ, Henriksen Z, Syberg S, Petersen S Schwarz P, Jørgensen NR, van Helden S and Dagnelie PC: Association of $\mathrm{P} 2 \mathrm{X} 7$ receptor polymorphisms with bone mineral density and osteoporosis risk in a cohort of Dutch fracture patients. Osteoporos Int 24: 1235-1246, 2013.

26. Grol MW, Brooks PJ, Pereverzev A and Dixon SJ: P2X7 nucleotide receptor signaling potentiates the Wnt//-catenin pathway in cells of the osteoblast lineage. Purinergic Signal 12: 509-520, 2016

27. Lu W, Albalawi F, Beckel JM, Lim JC, Laties AM and Mitchell CH: The P2X7 receptor links mechanical strain to cytokine IL- 6 up-regulation and release in neurons and astrocytes. J Neurochem 141: 436-448, 2017.

28. Geraghty NJ, Belfiore L, Ly D, Adhikary SR, Fuller SJ, Varikatt W, Sanderson-Smith ML, Sluyter V, Alexander SI, Sluyter R and Watson D: The P2X7 receptor antagonist Brilliant Blue $G$ reduces serum human interferon- $\gamma$ in a humanized mouse model of graft-versus-host disease. Clin Exp Immunol 190 79-95, 2017.

29. Livak KJ and Schmittgen TD: Analysis of relative gene expression data using real-time quantitative PCR and the 2(-Delta Delta C (T)) method. Methods 25: 402-408, 2001

30. Sharma U, Pal D and Prasad R: Alkaline phosphatase: An overview. Indian J Clin Biochem 29: 269-278, 2014.

31. Romagnoli E, Minisola G, Carnevale V, Scillitani A, Frusciante V, Aliberti G and Minisola S: Assessment of serum total and bone alkaline phosphatase measurement in clinical practice. Clin Chem Lab Med 36: 163-168, 1998.
32. Fauran-Clavel MJ and Oustrin J: Alkaline phosphatase and bone calcium parameters. Bone 7: 95-99, 1986.

33. Langlois MR, Delanghe JR, Kaufman JM, De Buyzere ML, Van Hoecke MJ and Leroux-Roels GG: Posttranslational heterogeneity of bone alkaline phosphatase in metabolic bone disease. Eur J Clin Chem Clin Biochem 32: 675-680, 1994.

34. Wei J and Karsenty G: An overview of the metabolic functions of osteocalcin. Rev Endocr Metab Disord 16: 93-98, 2015.

35. Lee NK, Sowa H, Hinoi E, Ferron M, Ahn JD, Confavreux C, Dacquin R, Mee PJ, McKee MD, Jung DY, et al: Endocrine regulation of energy metabolism by the skeleton. Cell 130: 456-469, 2007.

36. Wei J, Hanna T, Suda N, Karsenty G and Ducy P: Osteocalcin promotes $\beta$-cell proliferation during development and adulthood through Gprc6a. Diabetes 63: 1021-1031, 2014.

37. Pi M, Nishimoto SK and Quarles LD: GPRC6A: Jack of all metabolism (or master of none). Mol Metab 6: 185-193, 2017.

38. Wu M, Ai W, Chen L, Zhao S and Liu E: Bradykinin receptors and EphB2/EphrinB2 pathway in response to high glucose-induced osteoblast dysfunction and hyperglycemia-induced bone deterioration in mice. Int J Mol Med 37: 565-574, 2016.

39. Nicke A, Kuan YH, Masin M, Rettinger J, Marquez-Klaka B, Bender O, Górecki DC, Murrell-Lagnado RD and Soto F: A functional P2X7 splice variant with an alternative transmembrane domain 1 escapes gene inactivation in P2X7 knock-out mice. J Biol Chem 284: 25813-25822, 2009.

(i) (2) This work is licensed under a Creative Commons Attribution-NonCommercial-NoDerivatives 4.0 International (CC BY-NC-ND 4.0) License. 